\title{
PENGEMBANGAN DESAIN PEMBELAJARAN TEMATIK INTEGRATIF BERBASIS PENDEKATAN CONTEXTUAL TEACHING AND LEARNING (CTL) KELAS 4 SEKOLAH DASAR
}

\author{
Oleh : Annisa Tiara Widya Saputri ${ }^{1)}$ Mawardi $^{2)}$ \\ PGSD FKIP Universitas Kristen Satya Wacana ${ }^{1,2)}$
}

\begin{abstract}
ABSTRAK
Desain pembelajaran tematik integratif yang digunakan guru dalam prosespembelajaran dinilai tidak sesuai dengan kondisi nyata siswa. Penelitian ini akan dikembangkan dengan penelitian R\&D yang meliputi tiga tahapan yaitu studi pendahuluan, pengembangan produk, dan pengujian. Teknik pengumpulan data yang digunakan adalah uji pakar, tes, dan nontes. Teknik tes yang digunakan adalah tes tertulis yang berbentuk pilihan ganda sedangkan teknik nontes menggunakan lembar angket dan observasi. Kevalidan desain pembelajaran dianalisis menggunakan uji pakar berupa deskriptif kategories dan presentase sedangkan teknik analisis data menggunakan uji T. Hasil dari penelitian desain pembelajaran tematik integratif dengan berbasis pendekatan CTL kelas 4 Sekolah Dasar setelah dilakukan uji pakar berupa: a) model desaindiperoleh rata -rata 16 dengan persentase $80 \%$. b) silabus pembelajaran mendapat rata-rata80,5 dengan persentase $76,6 \%$. c) RPP pembelajaran mendapat rata - rata 133 dengan presesntasi $83,1 \%$. d) materi pembelajaran mendapat rata - rata 65,5 dengan prsesntase $72,7 \%$. Desain pembelajaran terbukti efektif berdasarkan perbedaan pretes dan posttes pada taraf signifikansi 0,000. Jika diuji dengan taraf kepercayaan 0.05 maka diperoleh hasil $\alpha$ lebih kecil dari 0,05. Artinya kompetensi hasil belajar menggunakan Desain Pembelajaran Tematik Integratif Berbasis Pendekatan CTL lebih tinggi daripada Desain Pembelajaran Tematik Integratif rancangan dari Pemerintah.
\end{abstract}

Kata Kunci: Pengembangan Desain Pembelajaran, Tematik Integratif, Model Pendekatan Ctl.

\section{PENDAHULUAN}

Pendekatan tematik integratif dalam kurikulum 2013 ini bertujuan untuk meningkatkan mutu proses dan hasil pendidikan, yang mengarah pada pembentukan budi pekerti dan akhlak mulia secara utuh, terpadu, dan, seimbang, seimbang sesuai dengan Standar Kompetensi Lulusan (SKL) pada setiap satuan pendidikan. Dalam implementasi kutikulum 2013 diharapkan siswa mampu secara mandiri meningkatkan dan menggunakan pengetahuannya, mengkaji, menganalisis, dan mempersonalisasikan nilai - nilai karakter serta akhlak mulia sehingga terwujud dalam perilaku sehari hari.

Implementasi kurikulum 2013 di SD dilakukan dengan mengacu pada daftar tema yang telah ditentukan oleh Kementerian Pendidikan dan Kebudayaan (Kemendikbud) Republik Indonesia. Jumlah tema di setiap kelas berbeda beda, paling sedikit ada lima buah tema dan paling banyak ada sembilan tema. Tema - tema pada kelas 4 SD ada sembilan, antara lain: 1) indahnya kebersamaan, 2) selalu berhemat energi, 3) peduli terhadap makhluk hidup, 4) berbagai pekerjaan, 5) pahlawanku, 6) cita 
- citaku, 7) indahnya keragaman di negeriku, 8) daerah tempat tinggalku, 9) kayanya negeriku.

Kemendikbud menerbitkan buku seri pembelajaran tematik untuk pegangan guru dan siswa. Buku tersebut diterbitkan untuk tiap tema, bukan tiap mata pelajaran. Sehingga, untuk buku kelas 4 terdiri dari sembilan buku, tiap buku meliputi tujuh mata pelajaran kecuali pendidikan agama dan budi pekerti. Namun, di dalam buku tematik kelas 4 revisi 2016 tema 6 - 9 mata pelajaran matematika tidak lagi dicantumkan ke dalam buku tema. Tiap tema terdiri dari tiga subtema yang diuraikan menjadi enam pembelajaran. Tiap pembelajaran dilaksanakan untuk mencapai lebih dari satu kompetensi dasar yang saling berkaitan dari satu atau lebih mata pelajaran.

Berdasarkan hasil pengamatan yang dilakukan oleh peneliti ditemukan bahwa di dalam buku pegangan siswa Tema 3 Subtema 1 yang berjudul "Hewan dan Tumbuhan di Lingkungan Rumahku" kelas 4 SD yang diterbitkan Kemedikbud tidak sesuai dengan isi materi. Di sana di sebutkan bahwa subtema 1 memuat materi tentang hewan dan tumbuhan di lingkungan rumah, namun kenyataan yang ditemukan adalah di dalam subtetema tersebut tidak memuat materi tentang hewan dan hanya membahas tentang tumbuhan saja. Hal ini mengakibatkan siswa mengalami kesulitan untuk memahami. Selain itu pembelajaran yang diikuti oleh siswa terkadang tidak sesuai dengan keadaan atau situasi dunia nyata siswa, sehingga siswa tidak bisa menerapkan pengetahuan yang telah diperolehnya ke dalam kehidupan sehari hari.

Berdasarkan masalah yang ditemui seharusnya dilakukan perubahan terhadap materi sehingga ada kesesuaian materi dengan judul subtema. Selain itu, perlu dilakukannya pengembangan desain pembelajaran yang disesuaikan dengan kondisi nyata siswa. Dalam hal ini, peneliti melakukan penelitian yang berjudul "Pengembangan Desain Pembelajaran Tematik Integratif Berbasis Pendekatan Contextual Teaching and Leraning (CTL) Kelas 4 Sekolah Dasar".Penelitian ini bertujuan untuk mengembangkan Desain Pembelajaran Tematik Integratif Berbasis Pendekatan Contextual Teaching and Learning (CTL), mengembangkan langkahlangkah Desain Pembelajaran Tematik Integratif Berbasis Pendekatan Contextual Teaching and Learning (CTL), mengetahui kualitas produk model pembelajaran tematik integratif ini, dan mengetahui seberapa tinggi kefektifan desain pembelajaran tematik integratif ini dapat meningkatkan kompetensi hasil belajar pesera didik. 
KAJIAN PUSTAKA

\begin{tabular}{|c|c|c|}
\hline Desain & Pembelajaran & Tematik \\
\hline Integratif & Berbasis & Pendekatan \\
\hline $\begin{array}{l}\text { Contextual } \\
\text { (CTL) }\end{array}$ & Teaching & Learnin \\
\hline
\end{tabular}

Desain Pembelajaran Tematik Integratif Berbasis Pendekatan Contextual Teaching and Learning (CTL) adalah upaya perencanaan proses pembelajaran terpadu yang menggunakan tema untuk mengaitkan beberapa mata pelajaran tertentu yang dilakukan dengan konsep kontekstual yaitu mengaitkan antara materi yang diajarkan dengan situasi dunia nyata siswa sehingga menikngkatkan kinerja peserta didik.

\section{Langkah - Langkah Desain Pembelajaran Tematik Integratif Berbasis Pendekatan Contextual Teaching and Learning (CTL)}

Untuk mencapai tujuan tertentu maka harus melewati suatu prosedur atau langkah-langkah tertentu. Langkahlangkah Desain pembelajaran Tematik Integratif berbasis pendekatan Contextual Teaching and Learning (CTL)ini diadaptasi dari Suparman (2014:131) yang pertama adalah memilih tema. Pada tahap memilih tema dilakukan pengembangan sub tema yang dipadukan dengan lingkungan sekitar sehingga sub tema yang dikembangkan sesuai dengan pendekatan Contextual Teaching and Learning (CTL). Pada tahap mengembangkan sub tema dihasilkan produk berupa jaringan sub-sub tema. Langkah kedua melakukan analisis SKL, KI, KD dan membuat Indikator menghasilkan produk berupa tabel analisis SKL, KI, KD dan membuat Indikator. Langkah ketiga membuat hubungan pemetaan antara $\mathrm{KD}$ dan indikator menghasilkan tabel keterhubungan KD dan indikator. Langkah keempat membuat jaringan KD. Pada tahap ini selain mengembangkan jaringan KD juga mengembangkan jaringan indikator yang akhirnya menghasilkan produk jaringan KD dan Indikator. Langkah kelima yaitu menyusun silabus yang menghasilkan silabus, dan langkah terakhir menyusun RPP yang menghasilkan RPP. Pada langkah penyusunan RPP terdapat tahap untuk mengembangkan materi, sehingga perlu dilakukan pengembangan materi. Materi yang dikembangkan disusun dalam Buku Siswa sehingga perlu melakukan penyusunan Buku siswa.

Tujuan Model Desain Pembelajaran Tematik Integratif Berbasis Pendekatan Contextual Teaching and Learning (CTL) adalah sebagai pedoman bagi guru dalam merancang dan mengembangkan pembelajaran Tematik Integratif yang digunakan guru untuk melaksanakan pembelajaran sehingga berdampak pada kompetensi Hasil Belajar.

Berdasarkan diskripsi di atas model desain pembelajaran Tematik Integratif 


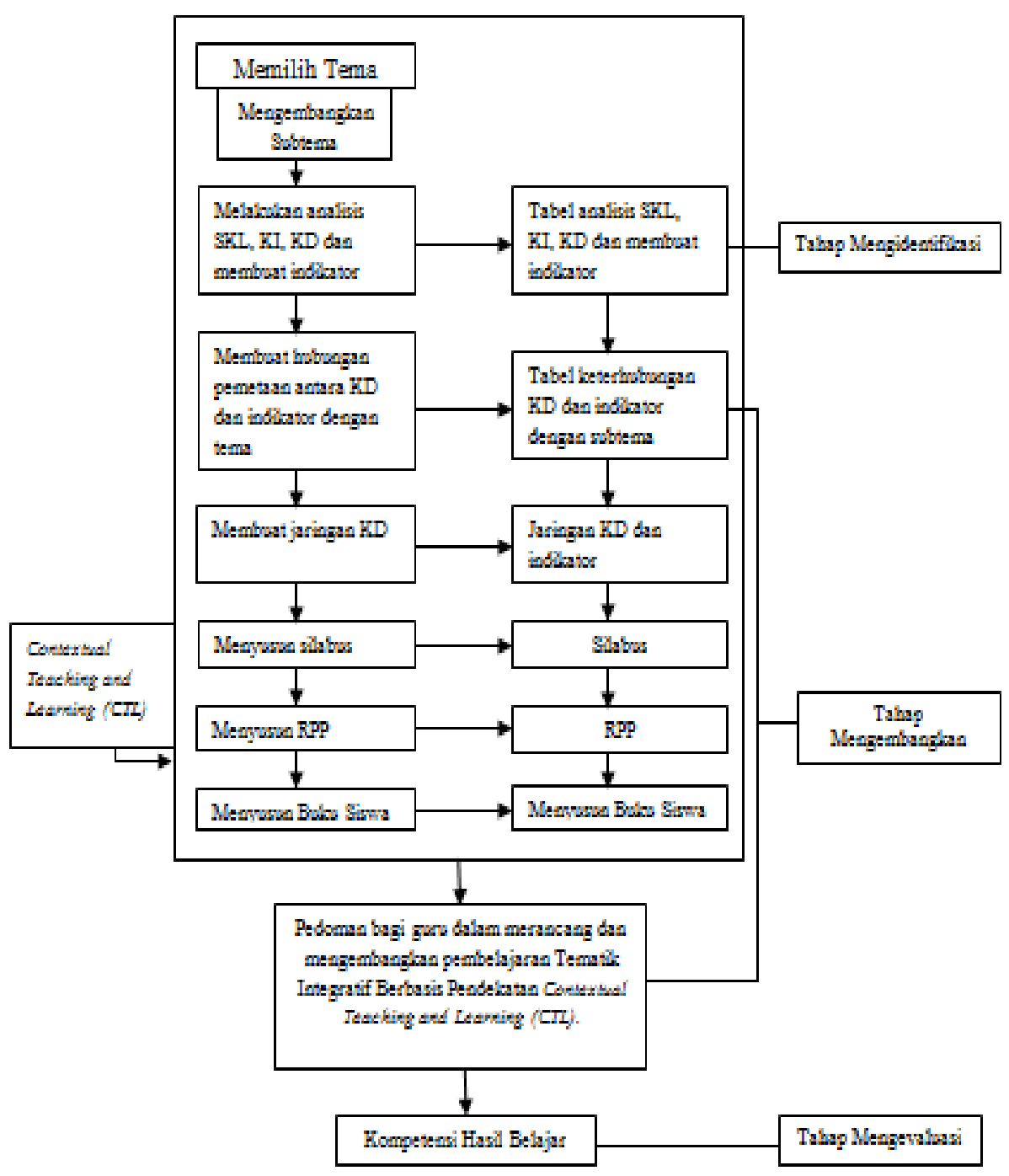

Gambar 1. Model Desain Pembelajaran Tematik integratif Berbasis Pendekatan Contextual Teaching and Learning (CTL)

\section{METODE PENELITIAN}

Secara rinciantahapan penelitian beserta tujuan, instrumen, sumber data dan pengolahan datapengembangan desain pembelajaran tematik integratif berbasis pendekatan CTL dapat dilihat pada tabel sebagai berikut: 
Tabel 1. Tahapan penelitian, tujuan, instrumen, sumber data dan pengolahan data pengembangan model desain pembelajaran tematik integratif berbasis pendekatan CTL

\begin{tabular}{|c|c|c|c|c|}
\hline $\begin{array}{c}\text { Tahapan } \\
\text { penelitian }\end{array}$ & Tujuan & Instrumen & $\begin{array}{c}\text { Sumber } \\
\text { data }\end{array}$ & $\begin{array}{c}\text { Pengo- } \\
\text { lahan data }\end{array}$ \\
\hline $\begin{array}{l}\text { 1. Studi } \\
\text { Pendahuluan } \\
\text { a. Studi } \\
\text { Pustaka } \\
\text { b. Survai } \\
\text { lapangan } \\
\text { c. Penyusunan } \\
\text { draft } \\
\text { produk } \\
\text { awal }\end{array}$ & $\begin{array}{l}\text { Untuk mendeskripsikn } \\
\text { model Desain } \\
\text { pembelajaran tematik } \\
\text { integratif menggunakan } \\
\text { model pendekatan } \\
\text { kontekstual, } \\
\text { permasalahan, dan } \\
\text { kebutuhan } \\
\text { pembelajaran. }\end{array}$ & $\begin{array}{l}\text { Observasi, } \\
\text { dan studi } \\
\text { dokumen } \\
\text { buku siswa, } \\
\text { silabus, dan } \\
\text { RPP. }\end{array}$ & $\begin{array}{l}\text { Guru dan } \\
\text { siswa } \\
\text { kelas } 4 \\
\text { SDN } \\
\text { Salatiga } \\
02 \text { dan } \\
\text { SDN } \\
\text { Salatiga } \\
06 .\end{array}$ & $\begin{array}{l}\text { Analisis data } \\
\text { deskriptif } \\
\text { presentase }\end{array}$ \\
\hline $\begin{array}{l}\text { 2. Pengem- } \\
\text { bangan }\end{array}$ & $\begin{array}{l}\text { Untuk mengembangkan } \\
\text { produk awal model } \\
\text { pembelajaran tematik } \\
\text { integratif menggunakan } \\
\text { model pendekatan } \\
\text { kontekstual }\end{array}$ & & & \\
\hline $\begin{array}{l}\text { a. Uji Validasi } \\
\text { Ahli }\end{array}$ & $\begin{array}{l}\text { Untuk menyempurnakan } \\
\text { dan memperoleh } \\
\text { validasi model serta } \\
\text { mengetahui kelebihan } \\
\text { dan kelemahan secara } \\
\text { konseptual menurut para } \\
\text { ahli. }\end{array}$ & $\begin{array}{l}\text { Rubrik } \\
\text { penilaian } \\
\text { ahli }\end{array}$ & $\begin{array}{l}\text { 4 Orang } \\
\text { Ahli }(2 \\
\text { Ahli } \\
\text { materi } \\
\text { dan } 2 \\
\text { Ahli } \\
\text { desain) }\end{array}$ & $\begin{array}{l}\text { Analisis } \\
\text { data } \\
\text { deskriptif } \\
\text { kategoris } \\
\text { dan } \\
\text { presentase }\end{array}$ \\
\hline $\begin{array}{l}\text { b. Uji coba } \\
\text { terbatas }\end{array}$ & $\begin{array}{l}\text { Untuk menerapkan } \\
\text { model dan mendapat } \\
\text { masukan untuk } \\
\text { perbaikan }\end{array}$ & & & \\
\hline $\begin{array}{l}\text { c. Uji coba } \\
\text { luas }\end{array}$ & Tidak dilakukan & $\begin{array}{l}\text { Angket, } \\
\text { observasi, } \\
\text { pretes, dan } \\
\text { postes }\end{array}$ & $\begin{array}{l}\text { Guru dan } \\
\text { siswa } \\
\text { kelas } 4 \\
\text { SDN } \\
\text { Salatiga } \\
02 \text { dan } \\
\text { SDN } \\
\text { Salatiga } \\
\text { 06. }\end{array}$ & $\begin{array}{l}\text { Analisis data } \\
\text { deskriptif } \\
\text { kategoris } \\
\text { dan } \\
\text { presentase } \\
\text { serta Uji T }\end{array}$ \\
\hline $\begin{array}{l}\text { 3. Pengujian } \\
\text { Eksperimental }\end{array}$ & Tidak dilakukan & & & \\
\hline
\end{tabular}




\section{HASIL PENELITIAN}

Penelitian ini merupakan jenis penelitian pengembangan atau $R \& D$. Langkah-langkah proses penelitian dan pengembangan menunjukkan suatu siklus yang diawali dengan adanya permasalahan yang membutuhkan pemecahan dengan menggunakan suatu produk tertentu. Proses pengembangan instrumen yang dilakukan dalam penelitian ini adalah tahapan-tahapan berdasarkan alur model pengembangan

penelitian Thiagarajan yang terdiri dari 4-D. Adapun model

pengembangan 4-D ini terdiri atas 4 tahap utama, yaitu (1) Define (pembatasan), (2) Design (perancangan), (3) Develop (pengembangan), dan (4) Disseminate (penyebaran). Tahap define adalah menetapkan dan mendefinisikan syarat - syarat pembelajaran diawali dengan analisis tujuan dari batasan materi yang dikembangkan perangkatnya. Tahap design yaitu untuk menyiapkan rancangan desain pembelajaran tematik integratif berbasis pendekatan CTL. Tahap develop meliputi penilian perangkat oleh para ahli, revisi, dan uji coba kepada siswa. Tahap disseminate adalah untuk mempromosikan produk pengembangan agar bisa diterima pengguna, baik individu, suatu kelompok, atau sistem.

Kualitas desain pembelajaran adalah ukuran kelayakan desain pembelajaran yang didasarkan pada kualitas silabus, RPP, dan penggalan buku siswa. Desain pembelajaran terbukti valid berdasarkan uji pakar yang dilakukan. Penilaian validator model desain diperoleh rata-rata 16 dengan persentase $80 \%$. Validator aspek silabus pembelajaran mendapat rata - rata 80,5 dengan persentase $76,6 \%$. Validator aspek RPP pembelajaran mendapat rata - rata 133 dengan presesntasi 83,1\%. Validator aspek materi pembelajaran mendapat rata - rata 65,5 dengan prsesntase $72,7 \%$.

Untuk mengetahui dampak perlakuan terhadap hasil belajar dilakukan uji $\mathrm{T}$ berdasarkan hasil postes kelas eksperimen dan kelas kontrol. 


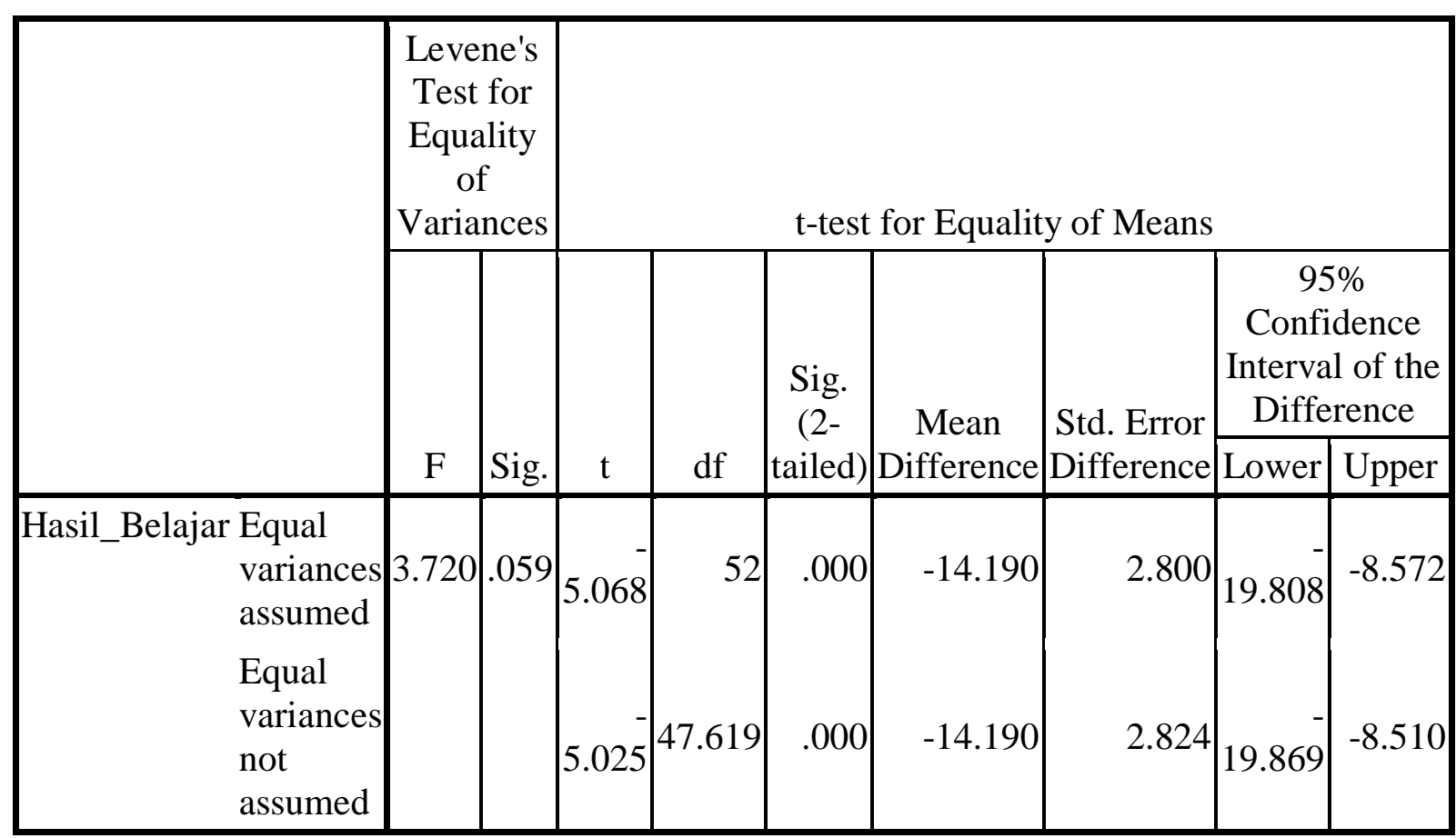

Tabel 2. Hasil Uji T Skor Postes Kelas Eksperimen dan Kelas Kontrol uji coba terbatas

Dari tabel diatas menunjukkan bahwa nilai $\mathrm{T}$ tabel 5,068 dengan nilai $\alpha$ 0,000. Jika diuji dengan taraf kepercayaan 0.05 maka diperoleh hasil $\alpha$ lebih kecil dari 0,05. Artinya kompetensi hasilbelajar menggunakan Desain Pembelajaran Tematik Integratif Berbasis Pendekatan CTL lebih tinggi daripada Desain Pembelajaran Tematik Integratif rancangan dari Pemerintah.Berdasarkan hasil dari uji $\mathrm{T}$ maka hipotesis penelitian ini $H I$ diterima yang artinya kompetensi hasil belajar menggunakan Desain Pembelajaran Tematik Integratif Berbasis Pendekatan CTL lebih tinggi dari Desain Pembelajaran Tematik Integratif rancangan dari Pemerintah. Selain itu dari uji $\mathrm{T}$ dapat disimpulkan $H I$ diterima karena $\mu 1 \geq \mu 2$ yang artinya kompetensi hasil belajar menggunakan Desain
Pembelajaran Tematik Integratif Berbasis Pendekatan CTL lebih tinggi dari Desain Pembelajaran Tematik Integratif rancangan dari Pemerintah. Pengambilan kesimpulan dilakukan berdasarkan nilai signifikansi yang diperoleh kurang dari 0,05, sehingga $H I$ diterima dan model dikatakan berhasil.

Deskripsi persentase pretes dan postes dirangkum dalam tabel di bawah ini.Penentuan jumlah kelas menggunakan rumus Sturges (Sugiyono, 2013: 35) yaitu $\mathrm{K}=1+3,3 \log \mathrm{n} . \mathrm{K}$ adalah jumlah kelas dan $\mathrm{n}$ adalah banyaknya data/siswa. Melalui rumus dapat diperoleh:

$$
\begin{aligned}
\mathrm{K} & =1+3,3 \log \mathrm{n} \\
& =1+3,3 \log 28 \\
& =1+3,3 \times 1,44 \\
& =5,75 \\
& =6
\end{aligned}
$$


Tabel 3. Hasil pretes dan postes siswa kelas 4 SD Negeri Salatiga 06

\begin{tabular}{cccc|cccc}
\hline \multirow{2}{*}{ No. } & Kelas & \multicolumn{2}{c|}{ Skor Pretes } & \multirow{2}{*}{ Ko. } & Kelas & \multicolumn{2}{c}{ Skor Postes } \\
\cline { 3 - 4 } & Interval & Frekuensi & Persentase & & Inerval & Frekuensi & Persentase \\
\hline 1. & $20-28$ & 2 & $7,7 \%$ & 1. & $65-69$ & 1 & $3,9 \%$ \\
2. & $29-37$ & 9 & $34,7 \%$ & 2. & $70-74$ & 5 & $19,2 \%$ \\
3. & $38-46$ & 3 & $11,5 \%$ & 3. & $75-79$ & 4 & $15,3 \%$ \\
4. & $47-55$ & 3 & $11,5 \%$ & 4. & $80-84$ & 2 & $7,7 \%$ \\
5. & $56-64$ & 5 & $19,2 \%$ & 5. & $85-89$ & 5 & $19,2 \%$ \\
6. & $\geq 65$ & 4 & $15,4 \%$ & 6. & $\geq 90$ & 9 & $34,7 \%$ \\
\hline \multicolumn{2}{r}{ Jumlah } & 26 & $100 \%$ & & Jumlah & 26 & $100 \%$ \\
\hline
\end{tabular}

Pada tabel dikatahui bahwa skor pretes dari 26 siswa SDN Salatiga 06 yang memperoleh skor antara 20 sampai 28 terdapat 2 siswa dengan persentase $7,7 \%$, antara 29 sampai 37 terdapat 9 siswa dengan persentase $34,7 \%$, antara 38 sampai 46 terdapat 3 siswa dengan persentase $11,5 \%$, antara 47 sampai 55 terdapat 3 siswa dengan persentase 11,5\%, antara 56 sampai 64 terdapat 5 siswa dengan persentase 19,2\% dan lebih dari sama dengan 65 terdapat 4 siswa dengan persentase $15,4 \%$.

Sedangkan diketahui skor postes dari 26 siswa diperoleh skor antara 65 sampai 69 terdapat 2 siswa dengan persentase $3,9 \%$, antara 70 sampai 74 terdapat 5 siswa dengan persentase 19,2\%, antara 75 sampai 79 terdapat 4 siswa dengan persentase $15,3 \%$, antara 80 sampai 84 terdapat 2 siswa dengan persentase $7,7 \%$, antara 85 sampai 89 terdapat 5 siswa dengan persentase $19,2 \%$, dan lebih dari sama dengan 90 terdapat 9 siswa dengan persentase $34,7 \%$.

Pada akhir pembelajaran siswa diminta mengisi lembar respon siswa dan semua siswa mengisi "Ya" yang menandakan siswa antusias mengikuti pembelajaran dan memberikan respon positif terhadap Desain Pembelajaran Tematik Integratif Berbasis Pendekatan CTL.

\section{PEMBAHASAN}

Beberapa peneliti sebelumnya juga sudah banyak yang mengembangkan tentang desain pembelajaran tematik integratif. Namun, banyak peneliti yang hanya mengembangkan desain pembelajaran tematik integratif tanpa menyesuaikan dengan kondisi nyata siswa atau dengan berbasis pendekatan CTL. 
Sehingga hasil penelitian ini menjadi kebaruan dari penelitian terdahulu.

Berdasarkan

penelitian

Fatchurrohman (2015) dengan judul "Pengembangan Model Pembelajaran Tematik Integratif Eksternal dan Internal di Madrasah Ibtidaiyah”. Berdasarkan penelitian ini menunjukkan hasil guru merasa nyaman dan cocok mengajar dengan model tersebut karena tidak harus melakukan pergantian jam pelajaran dari tema biasa ke pembelajaran PAI. Peserta didik juga terlihat senang mengikuti pembelajaran tersebut dan dari hasil evaluasinya menunjukkan hasil yang baik.Penelitian Jamaluddin (2015) dengan judul "Pengembangan Model Pembelajaran Tematik Terpadu Kontekstual Bagi Anak Usia Dini di Taman Kanak - Kanak Kelompok B”. Dalam penelitian ini menunjukkan hasil model dapat mendorong anak mampu lebih baik dalam melakukan observasi, bertanya, bernalar, dan mengkomunikasikan (mempresentasikan), apa yang mereka peroleh atau mereka ketahui setelah menerima materi pembelajaran. Guru juga memberikan respon positif dan menunjukan presentase kefektifan mencapai $\geq 90 \% .1$. Penelitian Sa'dun Akbar, I Wayan Sutama, Pujianto (2010) dengan judul "Pengembangan Model Pembelajaran Tematik untuk Kelas 1 dan Kelas 2 Sekolah Dasar". Secara umum penelitian ini dapat menghasilkan model-model pembelajaran tematik yang layak dan valid dengan tingkat validitas yang bervariasi, dapatd iterapkan dalam praktik pembelajaran sehari-hari di kelas, dan efektif dapat mencapai tujuan pembelajaran yang ditargetkan.

Berdasarkan ketiga penelitian terdahulu walaupun menunjukan model pembelajaran tematik diterima oleh guru dan layak digunakan. Penelitian ini menyumbang pengetahuan dalam segi pengembangangan desain pembelajaran juga memberikan pengetahuan dalam melihat perbedaan kompetensi hasil belajar siswa dengan menggunakan Desain Pembelajaran Tematik Integratif Berbasis Pendekatan CTL dengan Desain Pembelajaran Tematik Integratif dari Permendikbud.

Berdasarkan penelitian terdahulu juga mendukung penelitian ini terbukti bahwa dari kesepuluh model pembelajaran tematik integratif yang dikembangkan menunjukan cocok dan layak digunakan dalam pembelajaran di kelas rendah maupun dikelas tinggi, sehingga dapat dikatakan model desain pembelajaran tematik integratif berbasis pendekatan CTLmemang tepat diterapkan dalam pembelajaran di Sekolah Dasar.

Model desain pembelajaran integratif berbasis pendekatan CTL juga memiliki tujuan yang jelas dan dapat dijadikan 
pedoman bagi guru dalam merancang dan mengembangkan pembelajaran Tematik Integratif berbasis pendekatan CTL yang digunakan guru untuk melaksanakan pembelajaran. Pengembangan model desain pembelajaran yang dikembangkan ini dilengkapi dengan silabus, RPP, dan penggalan buku siswa. Penggalan buku siswa produk desain dapat digunakan siswa dalam belajar di sekolah maupun di rumah, silabus dan RPP yang dapat digunakan guru sebagai salah satu pedoman dalam melakukan proses belajar mengajar di kelas. Selain itu dapat digunakan sebagai bahan informasi guru dalam ketrampilan mengembangan Desain Pembelajaran Tematik Integratif Berbasis Pendekatan CTL yang lain.

Berdasarkan pemaparan model desain pembelajaran yang baik dapat disimpulkan bahwa model desain pembelajaran tematik integratif berbasis lingkungan memenuhi kriteria dan layak digunakan dalam pembelajaran di Sekolah Dasar.

\section{SIMPULAN}

Berdasarkan hasil penelitian dan pembahasan yang telah diuraikan dalam bab sebelumnya,maka diperoleh simpulan sebagai berikut.

1. Tingkat validitas model setelah mendapatkan penilaian dari ahli model desain pembelajaran mencapai $80 \%$ dengan kategori tinggi, validasi desain pembelajaran sebesar 80,3\% dengan kategori tinggi dan validasi materi oleh ahli materi sebesar $72,7 \%$ dengan kategori tinggi.

2. Berdasarkan hasil uji coba terbatas menggunakan eksperimen dengan teknik Uji T, kompetensi hasil belajar siswa yang menggunakan Desain Pembelajaran Tematik Integratif Berbasis Pendekatan Contextual Teaching and Learning (CTL) lebih tinggi daripada Desain Pembelajaran Tematik Integratif Rancangan dari Pemerintah. Temuan ini dilihat dengan nilai $\mathrm{t}$ hitung sebesar 5,068 dengan nilai signifikansi 0,000 . Sehingga Desain Pembelajaran Tematik Integratif Berbasis Pendekatan CTL yang dikembangkan dapat disimpulkan bahwa desain berhasil dan layak diterapkan di Kota salatiga dengan catatan dilakukan uji coba luas dan uji efektifitas terlebih dahulu sebelum disebarluaskan.

\section{SARAN}

Berdasarkan simpulan hasil penelitian dan pengembangan Desain Pembelajaran Tematik Integratif Berbasis Pendekatan CTL di atas, berikut disampaikan saran untuk menindak lanjuti pengembangan model ini agar lebih 
berkualitas sehingga dapat digunakan dalam proses pembelajaran, antara lain:

1. Bagi Guru

Guru seharusnye seharusnya selalu memperbaharui model-model/desain pembelajaran yang akan diterapkan di setiap kelas. Dalam konkretnya guru diharapkan mempelajari berbagai macam pendekatan - pendekatan dalam pelajaran, sehingga pembelajaran dapat bervariasi dan tidak monoton hanya dengan satu jenis model pembelajaran.

2. Bagi Lembaga Sekolah

Seperti saran yang telah disampaikan untuk guru tentunya hal ini dituntut lembaga sekolah memberikan stimulus kepada guru-guru mereka dalam bentuk mengikutsertakan guru-guru SD ini ke berbagai kegiatan diklat, workshop, magang, studi banding, dan lain lain.

3. Bagi Peneliti Lanjutan

Dapat dikembangkan lagi ujicobanya sampai ke uji luas, sehingga sampai terlihat sekali perbedaannya. Lakukan ujicobanya ke beberapa SD antara 4 sampai 6 SD dengan menggunakan kelas kontrol dan kelas eksperimen. Kembangkan lebih dari subtema untuk memperoleh hasil yang lebih baik.
Kelas Tinggi Sekolah Dasar. Journal Pedagogia UMSIDA, 4(2), 1-10.

Akbar, S., Sutama, I.W., \& Pujianto. (2010). Pengembangan Model Pembelajaran Tematik untuk Kelas 1 dan Kelas 2 Sekolah Dasar. Jurnal Pendidikan dan Pembelajaran (JPP), 11(1), 1-9.

Fatchurrohman. (2015). Pengembangan Model Pembelajaran Tematik Integratif Eksternal dan Internal di Madrasah Ibtidaiyah. E-Journal, 9(2), 1-22.

Jamaluddin. (2015). Pengembangan Model Pembelajaran Tematik Terpadu Kontekstual Bagi Anak Usia Dini di Taman Kanak - Kanak Kelompok B. E-Journal, 1(1), 1-28.

Kesuma, D. (2010). Contextual Teaching and Learning Sebuah Panduan Awal dalam Pengembangan PBM. Garut: Rahayasa.

Sugiyono. (2013). Metode Penelitian Pendidikan Pendekatan Kuantitatif, Kualitatif, dan R\&D. Bandung: Alfabeta.

Suparman, A. (2014). Desain Instruksional Modern. Jakarta: Erlangga.

\section{DAFTAR PUSTAKA}

Agustiningsih. (2015). Pengembangan Model Pembelajaran Tematik Berbasis Pada Pendekatan Scientific Mengacu Pada Kurikulum 2013 Untuk 